\title{
PENGARUH PENERAPAN STANDAR AKUNTANSI PEMERINTAHAN BERBASIS AKRUAL, SISTEM PENGENDALIAN INTERN DAN MOTIVASI KERJA TERHADAP KUALITAS LAPORAN KEUANGAN (Studi Kasus Pada Organisasi Perangkat Daerah Provinsi Papua)
}

\author{
Vania Annissa Holle ${ }^{1}$ \\ vania.annissa.va@gmail.com \\ Dr. Agustinus Salle., M.Ec ${ }^{2}$ \\ Mariolin Sanggenafa, SE., M.SA., Ak ${ }^{3}$ \\ Jurusan Akuntansi, Fakultas Ekonomi dan Bisnis Universitas Cenderawasih
}

\begin{abstract}
This research aims to analyze the influence of accrual-based accounting standard, internal control system, and motivation of work on the quality of financial statements. The population were in 34 departments in Papua Province. The samples of this study were 65 people. The research method was used purposive sampling with criterion are the heads and the staff of sub-divisions of finance who participating in making financial report. Data collection was done by distributing questionnaires directly to each departments in Province of Papua. The analysis technique was used multiple linear regression. This study concludes that accrual-based accounting standard, internal control system, and work motivation have positive and significant effect on the quality of financial statements.
\end{abstract}

Keyword : accrual-based accounting standard, internal control system, work motivation, quality of financial statements.

\section{PENDAHULUAN}

Dalam hal pengelolaan keuangan negara atau daerah, rakyat mempunyai hak untuk mengetahui bagaimana pemerintah pusat maupun pemerintah daerah mengelola dana untuk kepentingan rakyat. Hal ini secara tegas telah dirumuskan dalam Kerangka Konseptual Standar Akuntansi Pemerintahan Peraturan Pemerintah Nomor 71 Tahun 2010 Tentang Standar Akuntansi Pemerintahan, sehingga rakyat mempunyai hak untuk mendapatkan informasi-informasi keuangan secara menyeluruh dan pemerintah dituntut untuk dapat menyajikan dan mempublikasikan laporan keuangan secara kompleks agar dapat memenuhi kebutuhan informasi dari pengguna laporan keuangan. Sebuah laporan keuangan yang berkualitas menunjukkan bahwa laporan tersebut bermanfaat bagi para penggunanya. Laporan keuangan dikatakan dapat memenuhi kualitasnya jika laporan tersebut dapat berpengaruh dalam hal pengambilan keputusan (decision usefulness).

Laporan keuangan yang berkualitas harus memiliki empat karakteristik yang disebut juga dengan karakteristik kualitatif laporan keuangan. Menurut PP 71 tahun 2010 keempat karakteristik tersebut yaitu, Relevan, Andal, Dapat dibandingkan dan Dapat dipahami. Laporan keuangan berisi tentang informasi penting mengenai aktivitas-aktivitas yang dilakukan oleh organisasi sektor publik dan harus dipertanggung-jawabkan kepada publik, sehingga laporan keuangan harus disusun secara tepat waktu dan sesuai dengan standar akuntansi yang berlaku. Standar yang berlaku dalam lingkup pemerintahan adalah Standar Akuntansi Pemerintahan (SAP). Menurut Permadi (2013) SAP adalah suatu standar penyusunan laporan keuangan untuk lingkup pemerintahan yang di susun sesuai dengan

\footnotetext{
${ }^{1}$ Alumni Jurusan Akuntansi FEB Uncen

${ }^{2}$ Dosen Jurusan Akuntansi FEB Uncen

3 Dosen Jurusan Akuntansi FEB Uncen
} 
prinsip- prinsip akuntansi sebagai pedoman dalam hal penyusunan dan penyajian laporan keuangan pemerintah. Dengan demikian, SAP merupakan salah satu syarat dalam upaya untuk meningkatkan kualitas laporan keuangan pemerintah di Indonesia.

Untuk mewujudkan terciptanya laporan keuangan yang lebih transparan dan akuntabel pada lingkup pemerintahan, maka dibutuhkan adanya perubahan dan pembaharuan dalam hal kebijakan akuntansi, yaitu SAP. Dengan adanya perubahan dan pembaharuan tersebut, maka SAP diharapkan mampu memberikan pedoman pokok dalam penyusunan dan penyajian laporan keuangan pemerintah baik pemerintah pusat maupun pemerintah daerah secara lebih baik (Setiawan \& Gayatri, 2017).

Dalam PP 71 tahun 2010, disebutkan bahwa pemerintah harus menerapkan SAP berbasis akrual. SAP Berbasis Akrual adalah SAP yang mengakui pendapatan, beban, aset, utang, dan ekuitas dalam pelaporan finansial berbasis akrual, serta mengakui pendapatan, belanja, dan pembiayaan dalam pelaporan pelaksanaan anggaran berdasarkan basis yang ditetapkan dalam APBN/APBD.

Dilansir dari Detiknews (2016) ada perbedaan mendasar pada standar berbasis kas dan standar berbasis akrual. Standar berbasis kas hanya mencatat transaksi pada saat terjadinya transaksi kas. Sementara standar berbasis akrual, selain mencatat transaksi pengeluaran dan penerimaan kas, juga mencatat jumlah utang dan piutang. Sistem berbasis akrual memberikan gambaran yang lebih akurat atas kondisi keuangan pemerintah daerah atau kota daripada sistem berbasis kas. Lebih jauh lagi, basis akrual mendukung penggunaan anggaran sebagai teknik pengendalian karena pada basis kas, pembayaran hanya direkam jika hal itu telah dilakukan. Hal ini sejalan dengan pendapat Rahmawati (2016) bahwa penerapan akuntansi berbasis akrual ditujukan untuk mengatasi kekurangan basis kas dalam memberikan data yang lebih akurat. Tujuannya untuk memberikan informasi yang lebih transparan mengenai pengelolaan keuangan yang dilakukan oleh pemerintah dan meningkatkan kualitas pengambilan keputusan di dalam pemerintah dengan menggunakan informasi yang diperluas, tidak sekedar basis kas.

Meskipun adanya perubahan penerapan SAP dari SAP Berbasis Kas Menuju Akrual menjadi SAP Berbasis Akrual, namun hal ini dianggap menjadi sebuah tantangan bagi pemerintah agar dapat meningkatkan kualitas laporan keuangan pemerintah daerah itu sendiri. Untuk mendukung keberhasilan implementasi standar akuntansi berbasis akrual, maka diperlukan adanya sumber daya manusia yang kompeten, komitmen atau dukungan dari pimpinan, sistem akuntansi, dan uji coba (Riandani, 2017).

Dilansir dari situs BPKP Perwakilan Provinsi Papua, di jelaskan bahwa pada Provinsi Papua, sejak Tahun Anggaran 2015 Pemerintah Provinsi Papua sudah menggunakan akuntansi berbasis akrual sesuai dengan PP 71 tahun 2010 dan Peraturan Menteri Dalam Negeri 64 tahun 2013. Pemprov Papua bekerjasama dengan Universitas Cenderawasih dan perwakilan Badan Pengawasan Keuangan dan Pembangunan (BPKP) untuk menggelar workshop mengenai implementasi SAP berbasis akrual di lingkungan Pemprov Papua yang diselenggarakan selama 2 hari mulai dari tanggal 23 Mei 2014 bertempat di hotel Aston. Dalam workshop ini, dihadiri oleh narasumber dari berbagai kalangan yaitu Komisi SAP, Perwakilan BPKP Provinsi Papua, Tim asistensi BPKP pusat, Tim asistensi keuangan daerah, Perwakilan dari Universitas Cenderawasih, Perwakilan dari Universitas Hasanuddin, dan narasumber terkait lainnya.

Menurut Peraturan Pemerintah Nomor 60 Tahun 2008 Tentang Sistem Pengendalian Intern Pemerintah, Untuk dapat mewujudkan pengelolaan keuangan negara yang efektif, efisien, transparan, dan akuntabel, menteri/pimpinan lembaga, gubernur, dan bupati/walikota wajib melakukan pengendalian atas penyelenggaraan aktivitas pemerintahan. Pengendalian atas penyelenggaraan aktivitas pemerintahan dilaksanakan dengan berpedoman pada Sistem Pengendalian Internal Pemerintah (SPIP).

Tujuan dari SPIP adalah untuk memberikan keyakinan yang memadai bagi tercapainya : efektivitas dan efisiensi pencapaian tujuan penyelenggaraan pemerintahan negara; keandalan pelaporan keuangan; pengamanan aset negara; dan ketaatan terhadap peraturan perundang-undangan.

Kualitas laporan keuangan pemerintah daerah dapat ditentukan melalui seberapa baik pengendalian internal yang dilakukan oleh pemerintah. Semakin baik pengendalian internal dalam 
suatu institusi pemerintah, maka akan berdampak juga pada semakin tinggi kualitas laporan keuangannya.

Dalam pelaksanaan kegiatannya, pemerintah daerah harus memiliki sistem pengendalian internal yang baik. Dengan banyaknya kasus penyelewengan, seperti kasus korupsi, penyalahgunaan keuangan negara, pemborosan anggaran, dan kualitas laporan keuangan pemerintah yang buruk merupakan salah satu dampak adanya pelaksanaan sistem pengendalian internal yang lemah atau kurang baik (Widari \& Sutrisno, 2017).

Pengendalian intern merupakan suatu cara untuk mengarahkan, mengawasi, dan mengukur sumber daya suatu organisasi, serta berperan penting dalam pencegahan dan pendeteksian adanya kesalahan dan penyalahgunaan terutama dalam penyusunan laporan keuangan. Pengendalian intern terdiri atas kebijakan dan prosedur yang digunakan dalam mencapai sasaran dan menjamin atau menyediakan informasi keuangan yang andal,serta menjamin ditaatinya hukum dan peraturan yang berlaku. (Riandani, 2017).

Fakta yang terjadi di lapangan menunjukkan bahwa dari hasil pemeriksaan Badan Pemeriksa Keuangan (BPK) terhadap 537 LKPD yang dilaporkan dalam Ikhtisar Hasil Pemeriksaan Semester (IHPS) I tahun 2017, mengungkapkan bahwa terdapat 6.053 kelemahan SPI yang terdiri atas 2.156 permasalahan kelemahan sistem pengendalian akuntansi dan pelaporan, 2.657 permasalahan kelemahan sistem pengendalian pelaksanaan anggaran pendapatan dan belanja, dan 1.240 permasalahan kelemahan struktur pengendalian intern.

Salah satu rekomendasi BPK terhadap berbagai permasalahan mengenai kelemahan SPI tersebut adalah dengan memerintahkan pejabat yang bertanggung jawab agar membuat laporan keuangan sesuai dengan peraturan, memberikan pelatihan dan pembinaan pemahaman akuntansi dan pelaporan keuangan.

Salah satu faktor penentu lainnya yang dapat menentukan tinggi rendahnya kualitas laporan keuangan pemerintah daerah adalah motivasi kerja. Motivasi kerja sangat dibutuhkan karena motivasi kerja akan memberikan suatu dorongan dan semangat dalam bekerja. Salah satu strategi yang tepat untuk memberikan dorongan atau semangat dalam bekerja adalah dengan meningkatkan motivasi terhadap para pegawainya. karena tanpa adanya motivasi kerja tersebut, maka pegawai tidak akan memiliki semangat ataupun dorongan dalam melakukan segala tugas yang diberikan.

Menurut Setiawan \& Gayatri (2017) Motivasi merupakan hal yang paling mendasar yang harus dimiliki oleh seseorang, karena tanpa adanya motivasi untuk bekerja atau motivasi untuk memperoleh tujuan tertentu, maka sulit untuk menyelesaikan ataupun memperoleh tujuan yang dinginkan.Motivasi merupakan faktor penting dalam setiap pegawai untuk mencapai hasil kerja yang efektif. Motivasi diartikan juga sebagai suatu kekuatan yang mengarahkan perilaku manusia. Motivasi sebagai faktor yang memberikan dorongan atau semangat kepada seseorang untuk mengambil suatu keputusan yang dikehendaki.

Motivasi kerja di dalam pemerintahan lebih diarahkan untuk memberikan kekuatan dan dorongan dalam diri seorang pegawai yang akan mempengaruhi pelaksanaan tugas dan tanggung jawabnya terhadap pelayanan publik. Pemberian motivasi yang tepat kepada para pegawai akan menghasilkan kinerja yang optimal untuk melayani publik (Wahyuni, 2015). Penelitian ini merupakan replikasi dari penelitian terdahulu yang dilakukan oleh Setiawan \& Gayatri tahun 2017 tentang "Pengaruh Akuntansi Berbasis Akrual, Sistem Pengendalian Intern dan Motivasi Kerja Terhadap Kualitas Laporan Keuangan”. Setiawan \& Gayatri (2017) melakukan penelitian tersebut pada SKPD di kabupaten Gianyar dengan hasil bahwa Akuntansi berbasis akrual, Sistem pengendalian intern, dan Motivasi kerja berpengaruh terhadap kualitas laporan keuangan.

Perbedaan penelitian ini dengan penelitian sebelumnya yaitu terletak pada objek yang digunakan yaitu pada Organisasi Perangkat Daerah (OPD) Provinsi Papua. Berdasarkan latar belakang di atas, judul yang diangkat dalam penelitian ini adalah "Pengaruh Penerapan Standar Akuntansi Pemerintahan Berbasis Akrual, Sistem Pengendalian Intern dan Motivasi Kerja Terhadap Kualitas Laporan Keuangan”. 
Dengan demikian, perumusan masalah dalam penelitian ini adalah 1) Apakah penerapan standar akuntansi pemerintahan berbasis akrual berpengaruh terhadap kualitas laporan keuangan ? 2) Apakah sistem pengendalian intern berpengaruh terhadap kualitas laporan keuangan? dan 3) Apakah motivasi kerja berpengaruh terhadap kualitas laporan keuangan ?. Oleh karena itu, tujuan yang ingin dicapai dalam penelitian ini adalah : 1). Untuk menguji \& membuktikan mengenai pengaruh penerapan standar akuntansi pemerintahan berbasis akrual terhadap kualitas laporan keuangan. 2). Untuk menguji \& membuktikan mengenai pengaruh sistem pengendalian intern terhadap kualitas laporan keuangan. dan 3). Untuk menguji \& membuktikan mengenai pengaruh motivasi kerja terhadap kualitas laporan keuangan. Manfaat yang dapat diperoleh dalam penelitian ini adalah 1). Untuk dapat memberikan referensi dan kontribusi untuk penelitian-penelitian selanjutnya dan penelitian analisis mengenai kualitas laporan keuangan. 2). Sebagai wawasan bagi pemerintah daerah tentang pengaruh penerapan standar akuntansi pemerintahan berbasis akrual, sistem pengendalian intern dan motivasi kerja terhadap kualitas laporan keuangan.

\section{TINJAUAN PUSTAKA}

\subsection{Agency Theory}

Prinsip utama teori ini menjelaskan bahwa terdapat hubungan kerja antara pihak yang memberi wewenang (prinsipal) dengan pihak yang menerima wewenang (agensi), dalam bentuk kontrak kerja sama yang disebut "nexus of contract". Dalam lingkup pemerintahan, hubungan keagenan tersebut juga terjadi yaitu antara rakyat yang berperan sebagai prinsipal dan pemerintahan yang berperan sebagai agensi (Riandani, 2017). Dalam penelitian ini, pemerintah merupakan agen yang mempunyai kewajiban untuk menyampaikan laporan keuangan yang berkualitas kepada masyarakat. Kualitas laporan keuangan pemerintah dapat menjadi salah satu tolak ukur dari pertanggungjawaban pemerintah selaku agen kepada masyarakat selaku prinsipal.

\subsection{Teori Akuntabilitas}

Menurut Udoyono (2012) akuntabilitas merupakan kewajiban untuk menyajikan dan melaporkan segala tindakan dan kegiatan, dalam hal ini terminologi akuntabilitas dilihat dari sudut pandang pengendalian tindakan pada pencapaian tujuan. Tolak ukur atau indikator pengukuran akuntabilitas adalah kewajiban individu dan organisasi untuk mempertanggungjawabkan capaian kinerjanya melalui pengukuran yang seobyektif mungkin. Dalam penelitian ini, laporan keuangan dikatakan berkualitas jika bersifat transparan dan akuntabel.

\subsection{Teori Hierarki Kebutuhan Abraham Maslow}

Teori ini menjelaskan bahwa terdapat 5 hierarki kebutuhan yang dimiliki oleh manusia yang menimbulkan motivasi bagi setiap individu untuk memenuhi kebutuhan tersebut. Menurut Nurcahyani (2010) berikut adalah susunan hierarki kebutuhan berdasarkan Teori Maslow: Kebutuhan dasar (physiological needs), Kebutuhan akan rasa aman (safety needs), Kebutuhan sosial (social and belongingness needs), Kebutuhan akan penghargaan (esteem needs), dan Kebutuhan akan aktualisasi diri (self actualization needs). Maslow memisahkan kebutuhan tersebut ke dalam urutan-urutan. Kebutuhan dasar dan kebutuhan akan rasa aman berada pada tingkat bawah. Sedangkan kebutuhan sosial, kebutuhan akan penghargaan dan kebutuhan akan aktualisasi diri berada pada tingkatan atas (Ferdiani, 2012). Dalam penelitian ini, salah satu faktor yang dapat menentukan tinggi rendahnya kualitas laporan keuangan pemerintah daerah adalah motivasi kerja para pegawai. Dalam bekerja, pegawai membutuhkan motivasi atau semangat dalam bekerja untuk memenuhi kebutuhannya. Berdasarkan teori hierarki kebutuhan Abraham Maslow, dapat diartikan bahwa jika kebutuhan- 
kebutuhan pegawai dapat terpenuhi, maka motivasi mereka dalam bekerja akan meningkat. Sehingga dapat berdampak pada peningkatan kualitas laporan keuangan.

\subsection{Kualitas Laporan Keuangan}

Kualitas merupakan suatu penilaian terhadap output pusat pertanggung jawaban atas suatu hal, baik dari segi yang berwujud seperti barang maupun segi yang tidak berwujud, seperti suatu kegiatan. Dalam laporan keuangan yang berkualitas, memiliki arti bahwa kepala daerah telah bertanggung jawab sesuai dengan wewenang yang diberikan kepadanya dalam hal pelaksanaan mengelola organisasinya (Riandani, 2017). Berdasarkan PP 71 tahun 2010, dijelaskan bahwa laporan keuangan pemerintah dapat dikatakan berkualitas jika memenuhi 4 karakteristik berikut : Relevan, Andal, Dapat Dibandingkan, dan Dapat Dipahami.

\subsection{Penerapan Standar Akuntansi Pemerintahan Berbasis Akrual}

Menurut PP 71 tahun 2010, Standar Akuntansi Pemerintahan berbasis akrual adalah SAP yang mengakui pendapatan, beban, aset, utang, dan ekuitas dalam pelaporan finansial berbasis akrual, serta mengakui pendapatan, belanja, dan pembiayaan berdasarkan basis yang ditetapkan dalam APBN/APBD. Komponen laporan keuangan terdiri dari : Laporan Realisasi Anggaran (LRA), Laporan Perubahan Saldo Anggaran Lebih (Laporan SAL), Neraca, Laporan Operasional (LO), Laporan Arus Kas, Laporan Perubahan Ekuitas (LPE) dan Catatan atas Laporan Keuangan (CaLK). Penerapan SAP berbasis akrual di dalam lingkungan pemerintah yaitu pada pemerintah pusat, pemerintah daerah dan satuan organisasi di lingkungan pemerintah pusat maupun pemerintah daerah (Langelo, Saerang, \& Alexander, 2015). Pada PP 71 tahun 2010 dijelaskan bahwa SAP Berbasis Akrual dilengkapi dengan Kerangka Konseptual Akuntansi Pemerintah dan dinyatakan dalam bentuk Pernyataan Standar Akuntansi Pemerintahan (PSAP).

\subsection{Sistem Pengendalian Intern}

Menurut PP 60 tahun 2008 Sistem Pengendalian Intern adalah proses yang integral pada tindakan dan kegiatan yang dilakukan secara berkelanjuta oleh pimpinan dan seluruh pegawai untuk memberikan keyakinan memadai atas tercapainya tujuan organisasi melalui kegiatan yang efektif dan efisien, keandalan pelaporan keuangan, pengamanan aset negara, dan ketaatan terhadap peraturan perundang-undangan. SPI terdiri atas beberapa unsur, yaitu: Lingkungan pengendalian, Penilaian risiko, Kegiatan pengendalian, Informasi dan komunikasi dan Pemantauan pengendalian intern.

\subsection{Motivasi Kerja}

Motivasi berasal dari bahasa latin movere yang berarti dorongan atau penggerakan. Secara umum motivasi dapat diartikan sebagai dorongan dan keinginan serta upaya yang timbul dari diri seorang individu untuk melaksanakan suatu kegiatan(Andiyanto, 2011). Setiap orang cenderung mengembangkan pola motivasi tertentu sebagai hasil dari lingkungan budaya tempat orang itu hidup. Pola ini berupa kebutuhan-kebutuhan yang mempengaruhi cara orang-orang yang memandang pekerjaan dan menjalani kehidupan mereka. Tiga kebutuhan yang sangat penting dalam motivasi kerja adalah prestasi, afiliasi, dan kekuasaan (Pratama, 2013). Dengan adanya motivasi dalam bekerja, maka para pegawai diharapkan lebih memiliki intensitas, arah dan ketekunan sehingga tujuan organisasi pun lebih mudah tercapai. 


\subsection{Penelitian Terdahulu dan Pengembangan Hipotesis}

\subsubsection{Pengaruh Penerapan Standar Akuntansi Pemerintahan Berbasis Akrual Terhadap} Kualitas Laporan Keuangan

Penelitian mengenai SAP berbasis akrual telah dilakukan oleh Kiranayanti \& Erawati (2016) dengan hasil bahwa Standar Akuntansi Pemerintahan Berbasis Akrual berpengaruh positif signifikan terhadap kualitas laporan keuangan daerah. Berdasarkan penjelasan tersebut, maka hipotesis yang diajukan dalam penelitian ini adalah:

H1 : Penerapan Standar Akuntansi Pemerintahan Berbasis Akrual berpengaruh terhadap kualitas laporan keuangan.

\subsubsection{Pengaruh Sistem Pengendalian Intern Terhadap Kualitas Laporan Keuangan}

Penelitian mengenai sistem pengendalian intern telah dilakukan oleh Satriawan (2016) yang menyatakan bahwa sistem pengendalian intern berpengaruh signifikan terhadap kualitas laporan keuangan. Artinya, semakin aktif keterlibatan atasan melakukan pengendalian intern dalam pengelolaan keuangan, maka kualitas laporan keuangan yang dihasilkan akan semakin baik. Berdasarkan penjelasan tersebut, maka hipotesis yang diajukan dalam penelitian ini adalah:

H2: Sistem Pengendalian Intern berpengaruh terhadap kualitas laporan keuangan.

\subsubsection{Pengaruh Motivasi Kerja Terhadap Kualitas Laporan Keuangan}

Penelitian mengenai motivasi kerja telah dilakukan oleh Setiawan \& Gayatri (2017) yang menyatakan bahwa variabel motivasi kerja berpengaruh positif pada kualitas laporan keuangan, hal ini bermakna bahwa dengan adanya motivasi kerja, dapat mendorong seseorang untuk bekerja secara maksimal sehingga menghasilkan kualitas laporan keuangan yang akurat. Berdasarkan penjelasan tersebut, maka hipotesis yang diajukan dalam penelitian ini adalah:

H3: Motivasi Kerja berpengaruh terhadap kualitas laporan keuangan

\subsection{Model Penelitian}

Berdasarkan penjelasan di atas, berikut adalah model penelitian yang menggambarkan hubungan antara penerapan SAP berbasis akrual, sistem pengendalian intern, motivasi kerja terhadap kualitas laporan keuangan.

\section{Gambar 1}

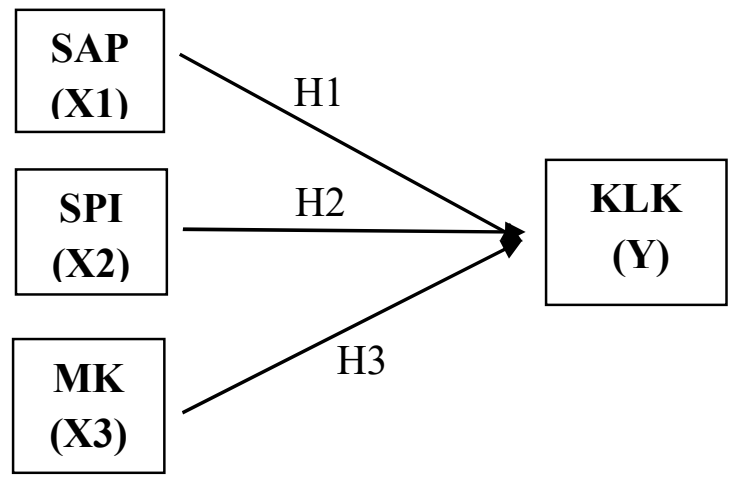




\section{METODE PENELITIAN}

\subsection{Jenis Penelitian}

Penelitian ini menggunakan pendekatan kuantitatif dengan tingkat eksplanasi penelitian berbentuk asosiatif. Pengujian hipotesis ini merupakan penelitian yang menjelaskan fenomena antara dua variabel atau lebih seperti pada penelitian ini untuk mengetahui adanya pengaruh antara penerapan standar akuntansi pemerintahan berbasis akrual, sistem pengendalian intern, dan motivasi kerja terhadap kualitas laporan keuangan.

\subsection{Populasi dan Sampel Penelitian}

Populasi dalam penelitian ini adalah Organisasi Perangkat Daerah (OPD) pada Provinsi Papua yang berjumlah 34 OPD. Sampel dalam penelitian ini adalah kepala sub bagian keuangan dan staf bagian keuangan pada setiap OPD, dengan total responden sebanyak 68 orang dengan 2 orang pada masing-masing OPD yang berjumlah 34 OPD. Teknik pengambilan sampel dilakukan dengan menggunakan metode purposive sampling dengan kriteria:

1) Pihak yang berwenang dalam pengambilan keputusan terkait laporan keuangan, yaitu Kasubag keuangan.

2) Staf pegawai bagian keuangan

Penelitian ini dilakukan di Organisasi Perangkat Daerah (OPD) Provinsi Papua pada bulan selama 3 bulan di tahun 2018

\subsection{Jenis dan Sumber Data}

Jenis data dalam penelitian ini adalah data kuantitatif yakni data kuesioner yang diisi oleh kasubag keuangan dan staf bagian keuangan. Sumber data dalam penelitian ini adalah data primer. Data primer diperoleh dari daftar pertanyaan dalam bentuk kuesioner yang diberikan secara langsung kepada responden.

\subsection{Instrumen Penelitian}

Instrumen yang digunakan dalam penelitian ini adalah kuesioner. Kuesioner terdiri dari sejumlah pertanyaan yang menggunakan skala likert dengan lima alternatif jawaban :

Tabel 3.1

Skala Pengukuran

\begin{tabular}{|l|c|c|}
\hline \multirow{2}{*}{ Skala Likert } & \multicolumn{2}{|c|}{ Sifat Pernyataan } \\
\cline { 2 - 3 } & $\begin{array}{c}\text { Positif } \\
(+)\end{array}$ & $\begin{array}{c}\text { Negatif } \\
(-)\end{array}$ \\
\hline $\begin{array}{l}\text { Sangat Setuju } \\
(\text { SS })\end{array}$ & 5 & 1 \\
\hline Setuju (S) & 4 & 2 \\
\hline Netral (N) & 3 & 3 \\
\hline Tidak Setuju (TS) & 2 & 4 \\
\hline $\begin{array}{l}\text { Sangat Tidak } \\
\text { Setuju (STS) }\end{array}$ & 1 & 5 \\
\hline
\end{tabular}




\subsection{Metode Pengumpulan Data}

Metode pengumpulan data dalam penelitian ini yakni dengan melakukan survey lapangan. Data yang dibutuhkan dalam penelitian ini adalah data primer. Teknik pengumpulan data yang digunakan dalam penelitian ini yaitu dengan menggunakan kuesioner untuk mendapatkan data primer. Kuesioner akan langsung diantarkan ke OPD Provinsi Papua.

\subsection{Definisi Operasional Variabel}

\subsubsection{Kualitas Laporan Keuangan}

Kualitas laporan keuangan adalah suatu penilaian mengenai baik atau buruknya hasil dari laporan keuangan, dimana penilaian ini dipengaruhi oleh karakteristik-karakteristik tertentu. Dalam penelitian ini, variabel diukur dengan karakteristik-karakteristik kualitatif laporan keuangan sesuai dengan PP 71 tahun 2010 yaitu relevan, andal, dapat dibandingkan, dan dapat dipahami.

\subsubsection{Standar Akuntansi Pemerintahan Berbasis Akrual}

Menurut PP 71 tahun 2010, SAP adalah prinsip-prinsip akuntansi yang diterapkan dalam menyusun dan menyajikan laporan keuangan pemerintah. Pada SAP berbasis akrual, pendapatan, beban, aset, utang, dan ekuitas diakui dalam pelaporan finansial berbasis akrual serta mengakui pendapatan, belanja, dan pembiayaan dalam pelaporan pelaksanaan anggaran berdasarkan basis yang ditetapkan dalam APBN/APBD. Dalam penelitian ini, indikator yang digunakan untuk mengukur variabel ini adalah pengakuan piutang, pengakuan persediaan dan pengakuan aset tetap.

\subsubsection{Sistem Pengendalian Internal}

Menurut PP 60 tahun 2008, Sistem Pengendalian Intern Pemerintah adalah proses yang integral pada tindakan dan kegiatan yang dilakukan secara terus menerus dan diselenggarakan secara menyeluruh di lingkungan pemerintah pusat dan pemerintah daerah oleh pimpinan dan seluruh pegawai untuk memberikan keyakinan memadai atas tercapainya tujuan organisasi melalui kegiatan yang efektif dan efisien, keandalan pelaporan keuangan, pengamanan aset negara, dan ketaatan terhadap peraturan perundang-undangan.

Dalam penelitian ini, variabel diukur melalui unsur-unsur SPI sesuai dengan PP nomor 60 tahun 2008 yaitu lingkungan pengendalian, penilaian risiko, kegiatan pengendalian, informasi dan komunikasi, dan pemantauan.

\subsubsection{Motivasi Kerja}

Motivasi kerja adalah suatu dorongan atau semangat untuk bekerja dikarenakan adanya kebutuhan yang mencakup aspek- aspek tertentu yang membuat diri seseorang melakukan rencana, membuat konsep, menyusun strategi, dan mengimplementasikannya melalui tindakan dengan penuh semangat yang tinggi dalam rangka mencapai kebutuhannya tersebut..

Dalam penelitian ini, variabel diukur dari pernyataan responden tentang kebutuhan akan prestasi, kebutuhan akan kekuasaan dan kebutuhan afiliasi.

\subsection{Teknik Analisis Data}

Dalam penelitian ini, teknik analisis yang digunakan adalah analisis linear berganda dengan bantuan SPSS 16.0. Metode ini menggambarkan suatu hubungan dimana satu atau lebih variabel (variabel independen) mempengaruhi variabel lainnya (variabel dependen) (Kusuma, 2013). Moden Regresi linear berganda dalam penelitian ini adalah:

$$
Y=a+\beta_{1} X_{1}+\beta_{2} X_{2}+\beta_{3} X_{3}+e
$$


Keterangan:

Y : Kualitas Laporan Keuangan

$\mathrm{X}_{1} \quad$ : Penerapan SAP Berbasis Akrual

$\mathrm{X}_{2} \quad$ : Sistem Pengendalian Intern

$\mathrm{X}_{3} \quad$ : Motivasi Kerja

$\alpha \quad$ : Konstan

$\beta_{1} \ldots \beta_{3}:$ Koefisien regresi

e $\quad:$ Error

\section{HASIL PENELITIAN DAN PEMBAHASAN}

\subsection{Gambaran Umum Responden}

\subsubsection{Tempat dan Waktu Penelitian}

Penelitian ini dilakukan di 34 Organisasi Perangkat Daerah (OPD) yang ada di Provinsi Papua. Setiap OPD masing-masing terdiri dari dua responden. Dari 34 OPD tersebut, kuesioner yang disebarkan berjumlah 68 buah dan jumlah kuesioner yang kembali sebanyak 65 kuesioner. Kuesioner yang tidak kembali sebanyak 3 buah dengan alasan hilang. Dengan demikian kuesioner yang dapat diolah berjumlah 65 buah. Penyebaran serta pengembalian kuesioner dilaksanakan mulai tanggal 17 Mei 2018 hingga 31 Mei 2018. Gambaran penyebaran dan pengembalian kuesioner dapat dilihat pada tabel berikut.

Tabel 4.1

Deskripsi Pengumpulan Data Kuesioner

\begin{tabular}{|c|l|c|c|}
\hline No & Keterangan & Jumlah & $\begin{array}{c}\text { Presentase } \\
(\mathbf{\%})\end{array}$ \\
\hline 1 & $\begin{array}{l}\text { Kuesioner yang } \\
\text { disebarkan }\end{array}$ & 68 & $100 \%$ \\
\hline 2 & $\begin{array}{l}\text { Kuesioner yang } \\
\text { tidak kembali }\end{array}$ & $(3)$ & $4,4 \%$ \\
\hline 3 & $\begin{array}{l}\text { Kuesioner yang } \\
\text { kembali }\end{array}$ & 65 & $95,6 \%$ \\
\hline
\end{tabular}

Sumber: Data Olah 2018

Berdasarkan Tabel 4.1 diatas terlihat bahwa dari 68 kuesioner yang disebar, terdapat 65 kuesioner yang dapat dikembalikan atau sebesar 95,6\%. Sementara kuesioner yang tidak dikembalikan berjumlah 3 kuesioner atau 4,4\%.

\subsubsection{Karakteristik Profil Responden}

Responden dalam penelitian ini berjumlah 65 orang yang berasal dari 34 Organisasi Perangkat Daerah di lingkungan Pemerintah Provinsi Papua. Dari hasil penelitian yang dilakukan, dapat diketahui beberapa karakteristik responden yang menjadi sampel dalam penelitian ini. Karakteristik responden tersebut disajikan dalam tabel tabel berikut : 
Tabel 4.2

Demografi Responden Berdasarkan Jenis Kelamin

\begin{tabular}{|l|l|l|l|}
\hline No & \multicolumn{1}{|c|}{$\begin{array}{c}\text { Jenis } \\
\text { Kelamin }\end{array}$} & Jumlah & $\begin{array}{c}\text { Persenta } \\
\text { se }\end{array}$ \\
\hline 1 & Pria & 37 & $57 \%$ \\
\hline 2 & Wanita & 28 & $43 \%$ \\
\hline & Jumlah & 65 & $100 \%$ \\
\hline
\end{tabular}

Sumber: Data Olah 2018

Berdasarkan Tabel 4.2 diatas dapat dilihat bahwa berdasarkan jenis kelamin, jumlah responden pria yang mengisi kuesioner berjumlah 37 orang (57\%), Sementara jumlah responden wanita yang mengisi kuesioner berjumlah 28 orang (43\%).

Tabel 4.3

Demografi Responden Berdasarkan Usia

\begin{tabular}{|c|l|c|c|}
\hline No & \multicolumn{1}{|c|}{ Usia } & Jumlah & $\begin{array}{c}\text { Persentas } \\
\text { e }\end{array}$ \\
\hline 1 & $20-30$ tahun & 4 & $7,1 \%$ \\
\hline 2 & $31-40$ tahun & 22 & $39,3 \%$ \\
\hline 3 & $41-50$ tahun & 17 & $30,4 \%$ \\
\hline 4 & $51-60$ tahun & 13 & $23,2 \%$ \\
\hline & Jumlah & 56 & $100 \%$ \\
\hline
\end{tabular}

Sumber: Data Olah 2018

Berdasarkan Tabel 4.3 diatas dapat dilihat bahwa berdasarkan usia, jumlah responden pada kelompok usia 20 - 30 tahun sebanyak 4 orang (7,1\%), jumlah responden pada kelompok usia 31 - 40 tahun sebanyak 22 orang $(39,3 \%)$, jumlah responden pada kelompok usia $41-50$ tahun sebanyak 17 orang $(30,4 \%)$ dan jumlah responden pada kelompok usia $51-60$ tahun sebanyak 13 orang $(23,2 \%)$.

Tabel 4.4

Demografi Responden Berdasarkan Tingkat Pendidikan

\begin{tabular}{|c|l|c|c|}
\hline No & $\begin{array}{c}\text { Pendidikan } \\
\text { Terakhir }\end{array}$ & Jumlah & Persentase \\
\hline 1 & S1 & 36 & $58 \%$ \\
\hline 2 & S2 & 15 & $24,2 \%$ \\
\hline 3 & D3 & 5 & $8,1 \%$ \\
\hline 4 & SMA & 6 & $9,7 \%$ \\
\hline & Jumlah & 62 & $100 \%$ \\
\hline
\end{tabular}

Sumber: Data Olah 2018 
Berdasarkan Tabel 4.4 diatas dapat dilihat bahwa berdasarkan tingkat pendidikan, responden yang merupakan lulusan S1 berjumlah 36 orang $(7,1 \%)$, lulusan S2 berjumlah 15 orang $(24,2 \%)$, lulusan D3 berjumlah 5 orang $(8,1 \%)$ dan lulusan SMA berjumlah 6 orang $(9,7 \%)$.

Tabel 4.5

Demografi Responden Berdasarkan Jabatan

\begin{tabular}{|c|l|c|c|}
\hline No & Jabatan & Jumlah & $\begin{array}{c}\text { Persentas } \\
\text { e }\end{array}$ \\
\hline 1 & $\begin{array}{l}\text { Kepala Sub } \\
\text { Bagian } \\
\text { Keuangan }\end{array}$ & 26 & $40 \%$ \\
\hline 2 & $\begin{array}{l}\text { Staff Bagian } \\
\text { Keuangan }\end{array}$ & 39 & $60 \%$ \\
\hline & Jumlah & 65 & $100 \%$ \\
\hline
\end{tabular}

Sumber: Data Olah 2018

Berdasarkan Tabel 4.5 diatas dapat dilihat bahwa berdasarkan jabatan, responden yang mempunyai jabatan sebagai Kepala Sub Bagian berjumlah 26 orang (40\%), sedangkan responden yang mempunyai jabatan sebagai Staff berjumlah 39 orang (60\%).

\subsection{Statistik Deskriptif}

Statistik deskriptif memberikan gambaran umum tentang objek penelitian yang dijadikan sampel. Statistik deskriptif dalam penelitian ini disajikan untuk memberikan informasi tentang karakteristik variabel penelitian, antara lain minimum, maksimum, mean, dan standar deviasi.

Tabel 4.6

\section{Statistik Deskriptif}

Descriptive Statistics

\begin{tabular}{|l|r|r|r|r|r|}
\hline & $\mathrm{N}$ & Minimum & Maximum & Mean & Std. Deviation \\
\hline SAP & 65 & 19 & 35 & 28.05 & 3.314 \\
MK & 65 & 31 & 48 & 41.34 & 3.360 \\
KLK & 65 & 19 & 25 & 22.38 & 1.774 \\
Valid N (listwise) & 65 & 38 & 50 & 43.91 & 3.916 \\
\hline
\end{tabular}

Sumber: Data Olah 2018

Berdasarkan Tabel 4.6 dapat disimpulkan bahwa jumlah pengamatan (N) penelitian ini berjumlah 65 . Nilai terendah dari data ditunjukkan oleh skor minimum, sedangkan nilai tertinggi dari data ditunjukkan oleh skor maksimum dalam tabel. Mean digunakan untuk mengukur nilai rata-rata dari data, dan standar deviasi menunjukkan simpangan baku.

Variabel kualitas laporan keuangan (Y) memiliki nilai minimum sebesar 38, nilai maksimum sebesar 50, nilai rata-rata sebesar 43,91 dan Standar Deviasi sebesar 3,916. Hal ini menunjukkan 
terjadi kualitas laporan keuangan dalam standar akuntansi pemerintahan berbasis akrual, sistem pengendalian intern, dan motivasi kerja pada Organisasi Perangkat Daerah, karena dapat dilihat nilai rata-rata lebih mendekati nilai maksimal.

Nilai minimum standar akuntansi pemerintahan berbasis akrual sebesar 19 dan nilai maksimumnya 35 dengan nilai rata-rata 28,05. Nilai rata-rata sebesar 28,05 menunjukkan bahwa responden menggunakan standar akuntansi pemerintahan berbasis akrual pada laporan keuangan. Standar deviasi pada variabel sistem akuntansi berbasis akrual adalah sebesar 3,314. Hal ini menunjukkan bahwa standar penyimpangan data terhadap nilai rata-ratanya adalah 3.314.

Nilai minimum sistem pengendalian intern sebesar 31 dan nilai maksimumnya 48 dengan nilai rata-rata 41,34. Nilai rata-rata sebesar 41,34 menunjukkan bahwa responden telah melakukan sistem pengendalian intern yang baik agar dapat tercapai kualitas laporan keuangan yang baik. Standar deviasi pada variabel sistem pengendalian intern adalah sebesar 3,360. Hal ini menunjukkan bahwa standar penyimpangan data terhadap nilai rata-ratanya adalah 3,360.

Nilai minimum motivasi kerja sebesar 19 dan nilai maksimumnya 25 dengan nilai rata-rata 22,38. Nilai rata-rata sebesar 22,38 menunjukkan bahwa responden cenderung memiliki motivasi kerja yang tinggi agar tercapainya kualitas laporan keuangan yang baik. Standar deviasi pada variabel motivasi kerja adalah sebesar 1,774. Hal ini menunjukkan bahwa standar penyimpangan data terhadap nilai rata-ratanya adalah 1,774 .

\subsection{Uji Validitas}

Pengujian ini dilakukan untuk mengukur sah atau validnya suatu kuesioner. Jika $\mathrm{r}$ hitung $<\mathrm{r}$ tabel maka nomor item tersebut tidak valid dan jika $r$ hitung $>r$ tabel maka item tersebut dinyatakan valid dan dapat digunakan untuk analisis selanjutnya, dimana $r$ tabel untuk penelitian ini,adalah 0,244. Dalam penelitian ini dapat disimpulkan bahwa $r$ hitung $>r$ tabel, yaitu hasil dari total korelasi setiap pernyataan lebih besar dari 0,244. Dengan demikian, semua butir pernyataan dalam kuesioner adalah valid.

\subsection{Uji Reliabilitas}

Uji reliabilitas digunakan untuk mengetahui sejauh mana hasil pengukuran tetap konsisten. Untuk uji reliabilitas digunakan rumus cronbach's alpha, jika nilai cronbach's alpha lebih besar dari 0,6 maka instrumen dikatakan reliabel.

Tabel 4.8

Uji Reliabilitas Data

\begin{tabular}{|l|c|c|c|}
\hline Variabel & $\begin{array}{c}\text { Cronbach's } \\
\text { Alpha }\end{array}$ & $\begin{array}{c}\mathrm{r} \\
\text { kritis }\end{array}$ & Keterangan \\
\hline SAP (X1) & 0,635 & 0,60 & Reliabel \\
\hline SPI (X2) & 0,781 & 0,60 & Reliabel \\
\hline MK (X3) & 0,656 & 0,60 & Reliabel \\
\hline KLK (Y) & 0,850 & 0,60 & Reliabel \\
\hline
\end{tabular}

Sumber: Data Olah 2018

Berdasarkan tabel 4.8 diatas, dapat disimpulkan bahwa Cronbach's Alpha masing-masing variabel lebih besar dari 0,60. Dengan demikian alat ukur dalam penelitian ini adalah reliabel. 


\subsection{Uji Asumsi Klasik}

\subsubsection{Uji Normalitas}

Bertujuan untuk menguji apakah dalam model regresi, variabel pengganggu atau residual memiliki distribusi normal. Uji normalitas dilakukan dengan menggunakan metode kolmogorov smirnov, dengan melihat nilai signifikansi pada 0,05 . Jika nilai signifikansi yang dihasilkan $>0,05$ maka data berdistribusi normal.

Tabel 4.9

Hasil Uji One-Sample Kolmogorov-Smirnov Test

\begin{tabular}{|ll|r|}
\hline \multicolumn{2}{|c|}{ One-Sample Kolmogorov-Smirnov Test } \\
\hline$N$ & & Unstandardized Residual \\
\hline Normal Parameters & \\
& & 65 \\
Most Extreme Differences & Mean & .0000000 \\
& Std. Deviation & 2.88159528 \\
& Absolute & .080 \\
Kolmogorov-Smirnov Z & Positive & .080 \\
Asymp. Sig. (2-tailed) & Negative & -.045 \\
\hline
\end{tabular}

a. Test distribution is Normal.

Sumber: Data Olah 2018

Berdasarkan hasil pengujian diatas dapat disimpulkan bahwa nilai probabilitas Asymp. Sig. (2-tailed) dalam penelitian ini memiliki nilai lebih besar dari 0,05 yaitu sebesar 0,797. Dengan demikian dapat dikatakan bahwa data terdistribusi normal.

\subsubsection{Uji Multikolinearitas}

Bertujuan untuk menguji apakah model regresi ditemukan adanya korelasi antar variabel bebas. Korelasi antar variabel independen ini dapat dideteksi dengan menggunakan Variance Inflation Factor (VIF). Untuk menguji adanya multikolinearitas dapat dilihat melalui nilai Variance Inflation Factor (VIF). Jika nilai tolerance lebih besar dari 0,1 dan nilai VIF lebih kecil dari 10, berarti model regresi bebas dari masalah multikolinearitas. Dalam penelitian ini nilai tolerance pada masingmasing variabel lebih besar dari 0,1 yaitu Standar Akuntansi Pemerintahan Berbasis Akrual 0,849, Sistem Pengendalian Internal 0,861 dan Motivasi Kerja 0,948. Nilai VIF pada masing-masing variabel kurang dari 10 yaitu Standar Akuntansi Pemerintahan Berbasis Akrual 1,178, Sistem Pengendalian Internal 1,162 dan Motivasi Kerja 1,054. Hal ini berarti model regresi bebas dari masalah multikolinearitas.

\subsubsection{Uji Heteroskedastisitas}

Model regresi yang baik adalah tidak mengetahui adanya heteroskedastisitas adalah dengan melihat ada/tidaknya pola tertentu pada grafik Scatter Plot. Model regresi dapat dikatakan bebas dari heteroskedastisitas adalah jika tidak membentuk pola yang jelas, serta titik-titik menyebar diatas dan dibawah angka 0 pada sumbu Y, maka tidak terjadi heteroskedastisitas. 


\section{Gambar 4.1}

\section{Uji Heteroskedastisitas}

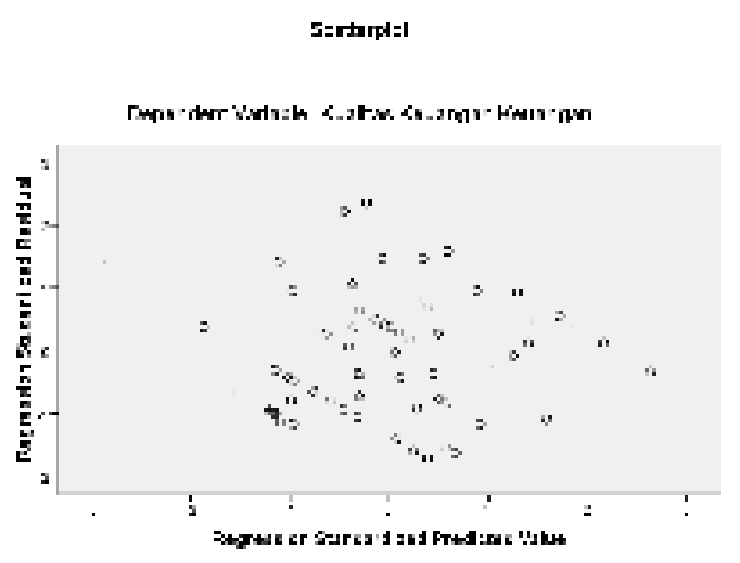

Sumber: Data Olah 2018

Berdasarkan gambar 4.1 diatas, dapat dijelaskan bahwa titik-titik pada grafik Scatterplot ini menyebar secara acak di atas dan dibawah angka nol pada sumbu Y. Dengan demikian dapat disimpulkan bahwa tidak ada gejala heterokedastisitas.

\subsection{Hasil Pengujian Hipotesis}

\subsubsection{Analisis Regresi Berganda}

Analisis Regresi Linear Berganda menggambarkan suatu hubungan dimana satu atau lebih variabel (variabel independen) mempengaruhi variabel lainnya (variabel dependen). Dalam penelitian ini Analisis Regresi Linear Berganda digunakan untuk melihat pengaruh Standar Akuntansi Pemerintahan Berbasis Akrual, Sistem Pengendalian Internal dan Motivasi Kerja terhadap Kualitas Laporan Keuangan. Berikut adalah hasil pengujian regresi berikut :

Tabel 4.10

\section{Hasil Analisis Regresi Linear Berganda}

\begin{tabular}{|l|r|r|r|}
\hline \multicolumn{1}{c|}{ Coefficients $^{\mathrm{a}}$} \\
& \multicolumn{1}{c|}{$\begin{array}{c}\text { Unstandardized } \\
\text { Coefficients }\end{array}$} & $\begin{array}{c}\text { Standardized } \\
\text { Coefficients }\end{array}$ \\
\cline { 2 - 4 } Model & \multicolumn{1}{|c|}{ B } & Std. Error & \multicolumn{1}{c|}{ Beta } \\
\hline 1 (Constant) & 4.957 & 6.111 & \\
S A P & .481 & .121 & .407 \\
SPI & .372 & .118 & .319 \\
M K & .450 & .214 & .204 \\
\hline
\end{tabular}

a. Dependent Variable: Kualitas

Keuangan Keuangan

Sumber: Data Olah 2018 
Berdasarkan hasil tabel di atas dapat diketahui nilai konstanta adalah 4,957, koefisien regresi variabel Standar Akuntansi Pemerintahan adalah 0,481, Sistem Pengendalian Internal adalah 0,372 dan Motivasi kerja sebesar 0,450. Berdasarkan analisa tersebut maka dibuat model regresi sebagai berikut

$$
\begin{aligned}
& \mathrm{Y}=\mathrm{a}+\boldsymbol{\beta}_{1} \mathrm{X}_{1}+\boldsymbol{\beta}_{2} \mathrm{X}_{2}+\beta_{3} \mathrm{X}_{3}+\mathrm{e} \\
& \mathrm{KLK}=4,957+0,481_{\mathrm{SAP}}+\mathbf{0 , 3 7 2} 2_{\mathrm{SPI}}+ \\
& 0,450 \mathrm{MK}+\mathrm{e}
\end{aligned}
$$

Berdasarkan persamaan di atas, dapat dijelaskan hal-hal sebagai berikut:

a. Nilai konstanta sebesar 4,957 menunjukan bahwa bila nilai variabel Standar Akuntansi Pemerintahan Berbasis Akrual (X1), Sistem Pengendalian Intern (X2), Motivasi Kerja (X3) sama dengan nol, maka nilai Kualitas Laporan Keuangan (Y) sebesar 4,957 satuan.

b. Nilai koefisien $\beta_{1}=0,481$ berarti menunjukkan bila nilai SAP (X1) bertambah 1 satuan, maka nilai dari Kualitas Laporan Keuangan (Y) akan mengalami kenaikan sebesar 0,481 satuan dengan asumsi variabel bebas lainnya konstan.

c. Nilai koefisien $\beta_{2}=0,372$ berarti menunjukkan bila nilai SPI (X2) bertambah 1 satuan, maka nilai dari Kualitas Laporan Keuangan (Y) akan mengalami kenaikan sebesar 0,372 satuan dengan asumsi variabel bebas lainnya konstan.

d. Nilai koefisien $\beta_{3}=0,450$ berarti menunjukkan bila nilai Motivasi Kerja (X3) bertambah 1 satuan, maka nilai dari Kualitas Laporan Keuangan (Y) akan mengalami kenaikan sebesar 0,450 satuan dengan asumsi variabel bebas lainnya konstan.

\subsubsection{Uji Koefisien Determinasi ( $\left(\mathrm{Uji} \mathbf{R}^{\mathbf{2}}\right)$}

Koefisien determinasi (R2) digunakan untuk menguji seberapa besar pengaruh variabel independen yaitu standar akuntansi pemerintahan berbasis akrual, sistem pengendalian internal dan motivasi kerja terhadap variabel dependen yaitu kualitas laporan keuangan. Nilai koefisien determinasi dapat dilihat pada tabel 4.12 berikut :

Tabel 4.11

Uji Koefisien Determinasi (Uji R²)

\section{Model Summary ${ }^{b}$}

\begin{tabular}{|l|r|r|r|r|}
\hline & & & & \\
Model & $\mathrm{R}$ & $\mathrm{R}$ Square & $\begin{array}{c}\text { Adjusted R } \\
\text { Square }\end{array}$ & $\begin{array}{c}\text { Std. Error of the } \\
\text { Estimate }\end{array}$ \\
\hline 1 & $.677^{\mathrm{a}}$ & .459 & .432 & \multicolumn{1}{c|}{2.952} \\
\hline
\end{tabular}

a. Predictors: (Constant), Motivasi Kerja, Sistem

Pengendalian Internal, Standar Akuntansi Pemerintah

b. Dependent Variable: Kualitas Keuangan Keuangan

Sumber: Data Olah 2018 
Berdasarkan tabel 4.11 dapat dilihat Nilai Adjusted $R$ Square sebesar 0,432 atau 43,2\%, ini menunjukkan bahwa kualitas laporan keuangan yang dapat dijelaskan oleh variabel standar akuntansi pemerintahan berbasis akrual, sistem pengendalian internal dan motivasi kerja adalah sebesar 43,2\%. Hal ini berarti variabel independen mempengaruhi variabel dependen sebesar $43,2 \%$ sedangkan sisanya 56,8\% dipengaruhi oleh variabel lain.

\subsubsection{Uji Parsial (Uji T)}

Uji T bertujuan untuk menguji pengaruh secara parsial antara variabel bebas terhadap variabel tidak bebas (Pratama, 2013). Hipotesis diterima apabila $t$ hitung $>\mathrm{t}$ tabel atau nilai $\operatorname{sig}<\alpha 0,05$. Sebaliknya hipotesis ditolak apabila $\mathrm{t}$ hitung $<\mathrm{t}$ tabel atau nilai sig $>\alpha 0,05$.

\section{Tabel 4.12}

Hasil Uji T

\begin{tabular}{|c|c|c|c|c|c|}
\hline \multirow{2}{*}{ Model } & \multicolumn{2}{|c|}{$\begin{array}{c}\text { Unstandardized } \\
\text { Coefficients }\end{array}$} & $\begin{array}{c}\text { Standardized } \\
\text { Coefficients }\end{array}$ & & \\
\cline { 2 - 4 } & $\mathrm{B}$ & Std. Error & Beta & $\mathrm{t}$ & Sig. \\
\hline (Constant) & 4.957 & 6.111 & & .811 & .420 \\
SAP & .481 & .121 & .407 & 3.980 & .000 \\
SPI & .372 & .118 & .319 & 3.144 & .003 \\
MK & .450 & .214 & .204 & 2.109 & .039 \\
\hline
\end{tabular}

a. Dependent Variable: Kualitas Laporan Keuangan

Sumber: Data Olah 2018

Berdasarkan tabel 4.12 dapat disimpulkan sebagai berikut :

\section{HIPOTESIS 1}

Variabel Standar Akuntansi Pemerintahan Berbasis Akrual (X1) nilai t hitung 3,980 > t tabel 2,000 dan nilai signifikan Standar Akuntansi Pemerintahan Berbasis Akrual (X1) yaitu 0,00<0,05. Dengan hasil analisa tersebut maka hipotesis pertama diterima, artinya berpengaruh dan signifikan terhadap laporan keuangan pemerintah.

\section{HIPOTESIS 2}

Variabel Sistem Pengendalian Internal (X2) nilai $t$ hitung 3,144 $>\mathrm{t}$ tabel 2,000 dan nilai signifikan Sistem Pengendalian Internal $(X 2)$ yaitu $0,003<0,05$. Dengan hasil analisa tersebut maka hipotesis kedua diterima, artinya berpengaruh dan signifikan terhadap laporan keuangan pemerintah.

\section{HIPOTESIS 3}

Variabel Motivasi Kerja (X3) nilai t hitung 2,109 > t tabel 2,000 dan nilai Variabel Motivasi Kerja (X3) signifikan yaitu $0,039<0,05$. Dengan hasil analisa tersebut maka hipotesis ketiga diterima, artinya berpengaruh dan signifikan terhadap laporan keuangan pemerintah. 
4.7 Pembahasan Hasil Penelitian

4.7.1 Pengaruh Standar Akuntansi Pemerintahan Berbasis Akrual Terhadap Kualitas Laporan Keuangan

Hasil dari pengujian terhadap hipotesis pertama dilihat dari nilai thitung sebesar 3,980 dan nilai $\mathrm{t}$ tabel adalah 2,000, sehingga $\mathrm{t}$ hitung $>\mathrm{t}$ tabel, maka sesuai dengan kriteria dapat disimpulkan variabel standar akuntansi pemerintahan berpengaruh terhadap variabel kualitas laporan keuangan pemerintah daerah. Dengan demikian hipotesis kedua dapat diterima, dengan artian bahwa variabel Sistem Pengendalian Internal berpengaruh dan signifikan terhadap kualitas laporan keuangan pemerintah. Hasil dari penelitian ini sejalan dengan penelitian yang dilakukan oleh Setiawan \& Gayatri (2017), Wijayanti (2017), Kiranayanti \& Erawati (2016). Hal ini bermakna bahwa semakin tinggi pemahaman pegawai atas penerapan sistem akuntansi pemerintahan berbasis akrual, maka semakin tinggi pula pengaruhnya terhadap kualitas laporan keuangan. Hasil dari penelitian ini menunjukkan bahwa responden sudah mempunyai pemahaman yang cukup mengenai penerapan standar akuntansi pemerintahan berbasis akrual, sehingga berdampak pada peningkatan kualitas laporan keuangan.

\subsubsection{Pengaruh Sistem Pengendalian Internal Terhadap Kualitas Laporan Keuangan}

Hasil dari pengujian terhadap hipotesis kedua dilihat dari nilai t hitung sebesar 3,144 dan nilai $t$ tabel adalah 2,000. Sehingga $t$ hitung $>t$ tabel, maka sesuai dengan kriteria dapat dapat disimpulkan variabel Sistem Pengendalian Internal berpengaruh terhadap variabel kualitas laporan keuangan pemerintah daerah. Dengan demikian hipotesis kedua dapat diterima, dengan artian bahwa variabel Sistem Pengendalian Internal berpengaruh dan signifikan terhadap kualitas laporan keuangan pemerintah. Hasil dari penelitian ini juga sejalan dengan penelitian yang dilakukan oleh Satriawan (2016), Riandani (2017), dan Saputra (2015). Hal ini bermakna bahwa dengan adanya sistem pengendalian internal yang baik dalam suatu organisasi maka akan berdampak pada peningkatan kualitas laporan keuangan. Hasil penelitian ini menunjukkan bahwa responden telah menerapkan sistem pengendalian internal yang baik dalam lingkungan organisasinya dengan tujuan agar dapat mencapai kualitas laporan keuangan yang lebih baik.

\subsubsection{Pengaruh Motivasi Kerja Terhadap Kualitas Laporan Keuagan}

Hasil dari pengujian terhadap hipotesis ketiga dilihat nilai t hitung sebesar 2,109 dan nilai $t$ tabel adalah 2,000. Sehingga t hitung $>t$ tabel, maka sesuai dengan kriteria dapat dapat disimpulkan variabel Motivasi Kerja berpengaruh terhadap variabel kualitas laporan keuangan pemerintah daerah. Dengan demikian hipotesis ketiga dapat diterima, dengan artian bahwa variabel Motivasi Kerja berpengaruh dan signifikan terhadap kualitas laporan keuangan pemerintah. Hasil dari penelitian ini sejalan dengan penelitian yang dilakukan oleh Setiawan \& Gayatri (2017) yang menyatakan bahwa dengan adanya motivasi kerja dari para pegawai, maka akan menghasilkan kualitas laporan keuangan yang baik. Sejalan dengan penelitian yang dilakukan oleh Sutawan (2015) dengan hasil bahwa dengan adanya motivasi kerja yang baik dari pegawai maka tujuan organisasi dapat tercapai, salah satunya yaitu untuk meningkatkan kualitas laporan keuangan. Hasil dari penelitian ini menunjukkan bahwa responden mempunyai motivasi/dorongan/ niat dalam melakukan pekerjaannya, dengan kata lain responden mempunyai semangat dalam bekerja sehingga dapat menghasilkan laporan keuangan yang berkualitas. 


\section{PENUTUP}

\subsection{Kesimpulan}

Berdasarkan hasil penelitian mengenai pengaruh akuntansi berbasis akrual, sistem pengendalian intern, dan motivasi kerja pada kualitas laporan keuangan Satuan Kerja Perangkat Daerah Kabupaten Gianyar dapat disimpulkan bahwa:

1. Variabel standar akuntansi pemerintahan berbasis akrual berpengaruh positif pada kualitas laporan keuangan, hal ini bermakna bahwa dengan adanya pemahaman mengenai standar akuntansi pemerintahan berbasis akrual maka akan berdampak pada peningkatkan kualitas laporan keuangan.

2. Variabel sistem pengendalian intern berpengaruh positif pada kualitas laporan keuangan, hal ini bermakna bahwa dengan adanya sistem pengendalian internal yang baik dalam suatu organisasi maka akan berdampak pada peningkatan kualitas laporan keuangan.

3. Variabel motivasi kerja berpengaruh positif pada kualitas laporan keuangan, hal ini bermakna bahwa dengan adanya motivasi kerja dapat mendorong seseorang untuk bekerja secara maksimal sehingga menghasilkan kualitas laporan keuangan yang akurat.

\subsection{Keterbatasan Penelitian}

Berdasarkan hasil penelitian terdapat beberapa keterbatasan yang mungkin dapat mempengaruhi hasil dari penelitian. Keterbatasan tersebut antara lain:

1. Pengumpulan data pada penelitian ini menggunakan metode kuesioner, sehingga memungkinkan terjadinya pengisian kuisioner yang tidak lengkap karena responden yang tidak bersungguhsungguh, sehingga dapat menimbulkan hasil yang tidak akurat.

2. Memerlukan waktu yang relatif lama untuk mendapatkan jawaban dari kuesioner di beberapa OPD di karenakan unsur kesibukan pegawai.

\subsection{Saran}

Berdasarkan hasil penelitian terdapat beberapa saran yang dapat dilakukan dalam penelitian mendatang antara lain :

1. Penelitian selanjutnya diharapkan dapat menggunakan metode penelitian yang berbeda seperti metode wawancara langsung kepada responden untuk memperoleh data yang lebih akurat.

2. Penelitian selanjutnya dapat menambahkan variabel lainnya yang dapat mendukung penelitian selanjutnya, seperti kapasitas sumber daya manusia.

3. Penelitian selanjutnya dapat memilih kuesioner yang dapat dipahami oleh responden, sehingga responden dapat memahami mengenai isi kuesioner. 


\section{DAFTAR PUSTAKA}

Andiyanto, W. (2011). Pengaruh Motivasi Kerja Dan Kepemimpinan Badan Keluarga Berencana Dan Pemberdayaan Perempuan Kabupaten Manggarai - Flores Nusa Tenggara Timur. Skripsi, 1-64. Retrieved from http://eprints.undip.ac.id/29481/

Detiknews. (2016). Raih WTP dari BPK, Wali Kota Makassar Dapat Piagam dari Kemenkeu. Retrieved December 20, 2016, from https://news.detik.com/berita/d-3375968/raih-wtp-daribpk-wali-kota-makassar-dapat-piagam-dari-kemenkeu/komentar

Ferdiani, D. (2012). Pengaruh Partisipasi Anggaran Terhadap Kinerja Manajerial Pegawai Sekretariat Daerah Provinsi Jawa Tengah: Komitmen Organisasi Dan Persepsi Inovasi Sebagai Variabel Intervening. Skripsi Undip, 1, 1-14. Retrieved from http://eprints.undip.ac.id/35820/

Kiranayanti, I. A. E., \& Erawati, N. M. A. (2016). Pengaruh Sumber Daya Manusia, Sistem Pengendalian Intern, Pemahaman Basis Akrual Terhadap Kualitas Laporan Keuangan Daerah. E-Jurnal Akuntansi, 16(2), 1290-1318. Retrieved from https://ojs.unud.ac.id/index.php/Akuntansi/article/view/18075

Kusuma, M. I. Y. (2013). Analisis Faktor-Faktor Yang Mempengaruhi Tingkat Penerapan Akuntansi Akrual Pada Pemerintah. Skripsi Universitas Diponegoro, 1-54. Retrieved from http://eprints.undip.ac.id/39563/

Langelo, F., Saerang, D. P. E., \& Alexander, S. W. (2015). Analisis Penerapan Standar Akuntansi Pemerintah Berbasis Akrual Dalam Penyajian Laporan Keuangan pada Pemerintah Kota Bitung. Jurnal EMBA, 3(1), 1-8. https://doi.org/10.1007/s13398-014-0173-7.2

Nurcahyani, K. (2010). Pengaruh Partisipasi Anggaran Terhadap Kinerja Manajerial Melalui Komitmen Organisasi Dan Persepsi Inovasi Sebagai Variabel Intervening. Skripsi Universitas Diponegoro. Retrieved from http: //eprints.undip.ac.id/23124/

Peraturan Pemerintah Nomor 60 Tahun 2008 Tentang Sistem Pengendalian Intern Pemerintah (2008). Indonesia.

Peraturan Pemerintah Nomor 71 Tahun 2010 Tentang Standar Akuntansi Pemerintahan (2010). Indonesia.

Permadi, A. D. (2013). Pengaruh Penerapan Sistem Akuntansi Keuangan Pemerintah Daerah Terhadap Kualitas Laporan Keuangan Pemerintah Daerah. Skripsi, 1-137. Retrieved from http://repository.widyatama.ac.id/xmlui/handle/123456789/2327

Pratama, R. (2013). Pengaruh Partisipasi Anggaran Terhadap Senjangan Anggaran Dengan Komitmen Organisasi Dan Motivasi Sebagai Pemoderasi ( Studi Empiris pada Satuan Kerja Perangkat Daerah di Kota Padang ). Artikel Ilmiah Universitas Negeri Padang, 1-20. Retrieved from http://ejournal.unp.ac.id/students/index.php/akt/article/view/53

Rahmawati, N. (2016). Implementasi Standar Akuntansi Pemerintahan Berbasis Akrual di Sekretariat DPRD Kabupaten Malang Berdasar Peraturan Pemerintah Nomor 71 Tahun 2010. Retrieved from http://ejournal.unikama.ac.id/index.php/jrma/article/view/1277

Riandani, R. (2017). Pengaruh Kompetensi SDM, Pemanfaatan Teknologi Informasi, dan Pengendalian Intern terhadap Kualitas Laporan Keuangan (Studi Empiris Pada SKPD Kab. Limapuluh Kota ). Artikel Ilmiah Universitas Negeri Padang. Retrieved from http://ejournal.unp.ac.id/students/index.php/akt/article/view/2395 
Saputra, B. W. (2015). Pengaruh Implementasi Standar Akuntansi Pemerintahan, Sistem Informasi Akuntansi dan Sistem Pengendalian Internal Terhadap Kualitas Laporan Keuangan Pemerintah Daerah (Studi Pada SKPD Kota Pekanbaru). Jurnal Online Manajemen Fakultas Ekonomi Vol. 2 No. 2 Oktober 2015, 2(2), 1-15. https://doi.org/10.1017/CBO9781107415324.004

Satriawan, I. (2016). Pengaruh Sistem Pengendalian Intern, Budaya Organisasional, dan Sumber Daya Manusia terhadap Kualitas Laporan Keuangan. JAFFA Vol. 04 No. 1 April 2016, 4(1), 18 29. https://doi.org/http://dx.doi.org/10.21107/jaffa.v4i1.1879

Setiawan, I. W. N., \& Gayatri. (2017). Pengaruh Akuntansi Berbasis Akrual, Sistem Pengendalian Intern dan Motivasi Kerja Pada Kualitas Laporan Keuangan. ISSN: 2302-8556 E-Jurnal Akuntansi Universitas Udayana Vol.21.1. Oktober (2017): 671-700, 21, 671-700. Retrieved from https://ojs.unud.ac.id/index.php/Akuntansi/article/view/33858

Sukmaningrum, T. (2012). Analisis Faktor Faktor yang Mempengaruhi Kualitas Informasi Laporan Keuangan Pemerintah Daerah. Skripsi Universitas Diponegoro. Retrieved from http://eprints.undip.ac.id/35305/1/Skripsi_15.pdf

Sutawan, I. M. E., Darmawan, N. A. S., \& Yuniarta, G. A. (2015). Pengaruh Stres Kerja, Sistem Pengendalian Intern dan Motivasi Kerja Pada Kualitas Laporan Keuangan Koperasi (Studi Kasus Pada Koperasi di Kabupaten Buleleng). E-Journal S1 Ak Universitas Pendidikan Ganesha Jurusan Akuntansi Program S1 (Volume 3 No.1 Tahun 2015), 3(1). Retrieved from https://ejournal.undiksha.ac.id/index.ph p/S1ak/article/view/5234

Udoyono, K. (2012). E-procurement dalam Pengadaan Barang dan Jasa untuk Mewujudkan Akuntabilitas di Kota Yogyakarta. Jurnal Studi Pemerintahan Vol. 3 No. 1 Februari 2012, 135171. Retrieved from http://journal.umy.ac.id/index.php/jsp/article/view/153

Wahyuni, E. (2015). Pengaruh Budaya Organisasi dan Gaya Kepemimpinan Terhadap Kinerja Pegawai bagian Keuangan Organisasi Sektor Publik Dengan Motivasi Kerja Sebagai Variabel Intervening. Jurnal Nominal Volume IV No. 1 Tahun 2015, 4, 96-112. https://doi.org/10.1017/CBO9781107415324.004

Widari, L., \& Sutrisno. (2017). Pengaruh Sistem Pengendalian Internal Pemerintah dan Komitmen Organisasi Terhadap Kualitas Laporan Keuangan Daerah. Jurnal Ilmiah Ilmu Ekonomi, 5(10), 117-126. Retrieved from http://eprints.ummi.ac.id/id/eprint/63

Wijayanti, R. (2017). Pengaruh kompetensi sdm dan implementasi akuntansi akrual terhadap kualitas laporan keuangan daerah. Jurnal Ilmu Dan Riset Akuntansi Volume 6,Nomor 3,Maret 2017, 6, 18. 